\title{
Monitoring Pengetahuan Tanya 50 dan Dagusibu Obat yang Benar pada Ibu PKK RT/RW 003/003 Desa Kedanyang, Kebomas, Gresik
}

\author{
Janatun Na'imah'1), Anindi Lupita Nasyanka²), Riskha Aulia ${ }^{3)}$ \\ 1,2,3) Prodi D3 Farmasi Fakultas Kesehatan Universitas Muhammadiyah Gresik, \\ 1) email : anindilupita@umg.ac.id
}

\begin{abstract}
ABSTRAK
Saat ini masyarakat kurang memahami tentang golongan-golongan obat yang dapat dibeli maupun disimpan di rumah. Hal ini dapat menimbulkan dua dampak, yaitu positif dan negatif. Dampak positifnya adalah masyarakat menjadi lebih tanggap terhadap kesehatan, sedangkan dampak negatifnya adalah meningkatnya penggunaan obat di masyarakat yang menimbulkan permasalahan terkait cara mendapatkan, menggunakan, menyimpan, dan membuang obat dengan benar atau dikenal dengan istilah Dagusibu. Kegiatan pengabdian masyarakat ini dilakukan untuk mengedukasi ibu rumah tangga sebagai "apoteker" di rumah tangga terkait bagaimana cara mendapatkan, menggunakan, menyimpan, dan membuang obat dengan benar di Desa Kedanyang RT/RW 003/003, Kebomas, Gresik. Metode yang digunakan adalah penyuluhan dan pelatihan yang disertai alat peraga berupa obat-obatan. Kemudian dilakukan monitoring menggunakan kuesioner yang dilakukan sebulan setelah penyuluhan. Penyuluhan dan pelatihan ini meliputi beberapa variabel, antara lain Tanya 5O, DApatkan, GUnakan, SImpan dan BUang. Hasil penyuluhan dan pelatihan mengenai obat terutama Dagusibu dapat dikatakan efektif dengan persentase menjawab benar masing-masing variabel lebih dari 75\%, yaitu "Tanya 50" sebanyak 97\%, DApatkan 84,38\%, GUnakan 87,14\%, SImpan $76 \%$, dan BUang 93\%. Hal tersebut membuktikan bahwa metode yang dipilih dalam pengabdian masyarakat ini sudah tepat, dimana masyarakat masih mengingat dan memahami materi yang disampaikan.
\end{abstract}

Kata-kata Kunci: Dagusibu, Edukasi, Penggunaan Obat Rasional

\begin{abstract}
At this time, community does not understand classes of drugs that can be purchase or stored at home. This can have two impacts, positive and negative. The positive impact is community become more responsive to health, while the negative impact is increasing use of drugs which raises problems related to how to get, use, store and dispose of drugs properly or commonly known as Dagusibu. This community service activity aims to educating housewives as "pharmacists" in the household regarding how to get, use, store, and dispose of drugs properly in Kedanyang Village RT/RW 003/003, Kebomas, Gresik. Method that we use in this community service is counseling and training using property and followed with monitoring. We use questionnaire for monitoring a month after counseling and training. Our method to counseling and training involve several variable, including Question of 5"O", Get, Use, Save and Discard (Dagusibu). The result shows that this activity is effective with the percentage of correct answer for each variable are above $75 \%$, including question about 5 "O" as much as $97 \%$, get $84.38 \%$, use $87.14 \%$, save $76 \%$, and waste $93 \%$. This proved that the method chosen in this community service is appropriate, where the community still remember and understand.
\end{abstract}

Keywords: Dagusibu, Education, Rational Drug Used

\section{PENDAHULUAN}

Kemajuan ilmu pengetahuan dan teknologi di industri obat seiring dengan perkembangan penyakit dan pemberlakuan program jaminan kesehatan mendorong munculnya bermacam-macam bentuk sediaan obat di masyarakat. Kemajuan tersebut juga didukung oleh kemajuan di bidang teknologi yang menyebabkan masyarakat menjadi lebih 
mudah untuk mendapatkan informasi, termasuk informasi tentang pengobatan. Kemajuankemajuan tersebut memiliki dampak positif dan negatif. Menurut Riset Kesehatan Dasar (Riskesdas) 2013, 35,2\% rumah tangga menyimpan obat untuk swamedikasi (pengobatan sendiri). Dari jumlah tersebut, $35,7 \%$ di antaranya menyimpan obat keras serta $27 \%$ diantaranya adalah antibiotik (Riskesdas, 2013). Data tersebut menunjukkan bahwa kurangnya pengetahuan masyarakat terhadap golongan-golongan obat mana saja yang dapat dibeli maupun disimpan di rumah. Dampak positifnya adalah masyarakat menjadi lebih tanggap untuk kesehatan pribadi dan keluarganya; sedangkan dampak negatifnya adalah meningkatnya penggunaan obat di masyarakat. Dampak negatif ini dapat menyebabkan permasalahan terkait cara mendapatkan, menggunakan, menyimpan, dan membuang obat dengan benar atau biasa dikenal dengan istilah Dagusibu.

Rumah tangga adalah satuan terkecil dari masyarakat yang memerlukan informasi terkait Dagusibu. Anggota rumah tangga yang harus mengetahui informasi tersebut adalah terutama seorang ibu. Jika seorang ibu tepat dalam mengelola obat di dalam rumahnya, maka secara tidak langsung telah mendorong terwujudnya peningkatan kualitas kesehatan masyarakat. Desa Kedanyang merupakan salah satu desa di wilayah Kecamatan Gresik yang terletak di bagian selatan Gresik. Penduduk Desa Kedanyang didominasi oleh pendatang. Mata pencaharian dari penduduk di Desa Kedanyang bervariasi dari petani sampai karyawan. Ibu rumahtangganya juga memiliki latar belakang pendidikan yang bervariasi. Terkait perolehan obat, masyarakat Desa Kedanyang biasa mendapatkan obat dari puskesmas, klinik, atau swamedikasi melalui apotek atau swalayan yang tersedia di lingkungan sekitar. Selama ini belum diketahui tingkat pengetahuan masyarakat Desa Kedanyang (terutama ibu rumah tangga) terhadap pengeloaan obat di rumah.

Oleh karena itu, perlu diadakan kegiatan pengabdian masyarakat yang bertujuan untuk mengedukasi ibu rumah tangga sebagai "apoteker" di rumah mereka masing-masing terkait bagaimana cara mendapatkan, menggunakan, menyimpan, dan membuang (Dagusibu) obat dengan benar.

\section{METODE PELAKSANAAN}

\subsection{Rancangan Kegiatan}

Berdasarkan analisis situasi dan permasalahan mitra di Desa Kedanyang, maka dapat dijabarkan beberapa solusi pemecahan masalah, di antaranya yaitu:

1. Pelatihan kepada masyarakat terkait Dagusibu obat dengan benar dalam pengelolaan obat-obatan di rumah. Selama pelatihan, dilakukan simulasi dengan menggunakan peraga untuk memudahkan masyarakat memahami Dagusibu obat dengan benar 
2. Monitoring yang dilakukan satu bulan setelah pelatihan Dagusibu obat dengan benar dalam pengelolaan obat-obatan di rumah dilakukan

\subsection{Lokasi dan Partisipan Kegiatan Pengabdian Masyarakat}

Kegiatan Pengabdian Kepada Masyarakat yang dilaksakan pada tanggal 13 Juli 2019 ini memiliki tema eduksi Dagusibu obat dan dibagi dalam 4 materi yaitu Dapatkan, Gunakan, Simpan serta Buang. Kegiatan ini mengacu pada salah satu Program Ikatan Apoteker Indonesia (IAI) yaitu Gerakan Keluarga Sadar Obat (GKSO), yang disampaikan kepada ibu-ibu PKK RT03/RW03 Desa Kedanyang Gresik. Guna mengevaluasi hasil kegiatan, dilakukan monitoring hasil 1 bulan setelah pelaksanaan penyuluhan, yaitu pada 13-15 Agustus 2019.

Sasaran kegiatan adalah ibu-ibu PKK RT03/RW03 Desa Kedanyang Gresik. Kegiatan ini dihadiri oleh 20 peserta ibu rumah tangga, mahasiswa dan dosen D3 Farmasi Universitas Muhammadiyah Gresik.

\subsection{Bahan/Alat/Media}

Alat yang digunakan untuk penyuluhan dan monitoring adalah powerpoint, disertai alat peraga berupa obat-obatan untuk menjelaskan penggunaan obat, dan lembar monitoring.

\subsection{Metode}

Metode yang digunakan dalam kegiatan pengabdian masyarakat ini adalah presentasi atau ceramah menggunakan media powerpoint, disertai alat peraga berupa obatobatan untuk menjelaskan penggunaan obat. Disamping itu, terdapat sesi tanya jawab dan monitoring menggunakan kuesioner monitoring yang dilakukan sebulan setelah penyuluhan.

\subsection{Pengolahan dan Analisis Data}

Dilakukan tabulasi atas data yang diperoleh dengan menggunakan software komputer. Monitoring kegiatan dilakukan dengan menggunakan metode survei terhadap semua peserta yang hadir ketika presentasi penyuluhan dilaksanakan.

\section{HASIL DAN PEMBAHASAN}

\subsection{Gambaran Umum}

Wilayah Desa Kedanyang menurut geografis terletak di Kecamatan Kebomas Kabupaten Gresik. Desa Kedanyang didominasi dengan perumahan yang sebagian besar dari penduduknya merupakan pendatang. Mata pencaharian penduduknya sangat bervariasi dari sektor pertanian, karyawan hingga ibu rumah tangga dengan latar belakang pendidikan 
yang bervariasi pula. Belum diketahui tingkat pengetahuan masyarakat khususnya ibu di Desa Kedanyang tentang pengelolaan obat di rumah tangga, sehingga kegiatan ini bertujuan untuk mengedukasi ibu rumah tangga mengenai bagaimana cara mendapatkan, menggunakan, menyimpan dan membuang (Dagusibu) obat dengan baik.

\subsection{Pelaksanaan}

Kegiatan penyuluhan Dagusibu ini merupakan salah satu program promosi kesehatan yang sering dilaksanakan oleh apoteker di seluruh Indonesia. Program ini bertujuan untuk mengedukasi masyarakat tentang pentingnya pemahaman penggunaan obat secara baik dan benar, baik melalui resep dokter ataupun membeli sendiri di apotek.

Kegiatan ini dimulai dengan pembukaan dan sambutan oleh Ketua PKK setempat. Kemudian dilanjutkan sambutan oleh Ketua Program Studi DIII Farmasi yang menjelaskan mengenai tujuan, manfaat dan rangkaian kegiatan penyuluhan dan pelatihan penggunaan obat dengan baik dan benar.

Kegiatan penyuluhan dan pelatihan dilakukan secara bersama-sama dengan menggunakan beberapa alat peraga, yaitu beberapa obat dan simbol-simbol yang ada pada kemasan obat. Penyuluhan dan pelatihan pertama yang dilakukan adalah penjelasan definisi obat secara umum beserta klasifikasinya dan cara mendapatkan obat dengan benar. Klasifikasi obat diantaranya adalah obat bebas, obat bebas terbatas, obat keras dan obat wajib apotek. Penjelasan ini bertujuan untuk memberikan pengetahuan kepada masyarakat tentang resiko penggunaan obat tidak rasional, seperti pembelian obat di tempat yang tidak tepat dan pembelian antibiotik tanpa resep dokter. Hal ini dikarenakan kurangnya tingkat pengetahuan masyarakat mengenai resistensi antibiotik.

Penyuluhan dan pelatihan kedua adalah penjelasan tentang jenis-jenis sediaan obat beserta cara penggunaannya. Sediaan obat yang digunakan antara lain, obat oral, suppositoria, topical, inhalasi dan lain-lain. Cara penggunaan obat yang benar merupakan salah satu aspek yang penting untuk masyarakat. Hal ini dikarenakan masyarakat sering melakukan kesalahan dalam penggunaan obat yang diakibatkan kurangnya informasi lengkap yang disampaikan oleh petugas kesehatan ketika memberikan obat kepada pasien/masyarakat. Sebagai contoh adalah kesalahan dalam penggunaan sediaan obat, seperti inhalasi atau suntikan (insulin yang dapat digunakan oleh pasien tanpa adanya bantuan dari tenaga kesehatan).

Penyuluhan dan pelatihan ketiga adalah penjelasan tentang bagaimana cara penyimpanan dengan baik dan benar. Penjelasan ini bertujuan untuk menjaga kualitas obat yang dikonsumsi, sehingga tidak terjadi kerusakan pada obat tersebut. Kerusakan obat dapat berdampak negative saat digunakan, seperti keracunan atau timbulnya efek yang tidak diinginkan, sehingga menyebabkan obat tidak bekerja atau pengobatan tidak berjalan 
secara maksimal. Beberapa aspek yang perlu diperhatikan dalam penyimpanan obat, antara lain obat yang bersifat cukup sensitif terhadap sinar matahari langsung, serta kondisi tempat yang lembab/tidaknya yang dapat merusak sebagian atau seluruh komponen yang ada di dalam obat yang dikonsumsi.

Penyuluhan dan pelatihan keempat adalah cara pembuangan obat dengan baik dan benar yang bertujuan agar masyarakat memahami bagaimana cara membuang obat, baik obat kadaluwarsa (expired) ataupun rusak, sehingga masyarakat tidak membuang obat secara sembarangan. Faktor yang perlu diperhatikan saat pembuangan obat adalah persiapan dan lokasi pembuangan obat. Pembuangan obat yang tidak baik dan benar dapat memberikan kesempatan kepada orang lain yang tidak bertanggung jawab dalam penyalahgunaan penggunaan obat.

Setelah dilakukan penyuluhan dan pelatihan, dilanjutkan dengan sesi tanya jawab yang dapat dijadikan sebagai pendorong dan pembuka jalan bagi masyarakat untuk mengetahui dan memahami lebih lanjut tentang penggunaan obat dengan baik dan benar. Pada sesi tanya jawab, respon masyarakat sangat baik yang terlihat dari banyaknya pertanyaan yang disampaikan kepada pemateri. Hal tersebut menunjukkan hasil refleksi/bentuk keingintahuan masyarakat terhadap materi tersebut yang dapat menimbulkan dampak positif bagi masyarakat.

\section{Tahap 1: Penyuluhan tentang Dagusibu}

Kegiatan penyuluhan disertai dengan monitoring yang dilakukan sebulan setelah penyuluhan. Monitoring ini bertujuan untuk mengetahui bagaimana tingkat pengetahuan dan penerapan dari hasil penyuluhan pada ibu - ibu PKK di RT. 03/RW. 003 Desa Kedanyang, Kecamatan Kebomas, Kabupaten Gresik (Gambar 1). Hal ini diharapkan agar tercipta masyarakat dengan tingkat pengetahuan yang sangat baik tentang Dagusibu obat dengan benar.
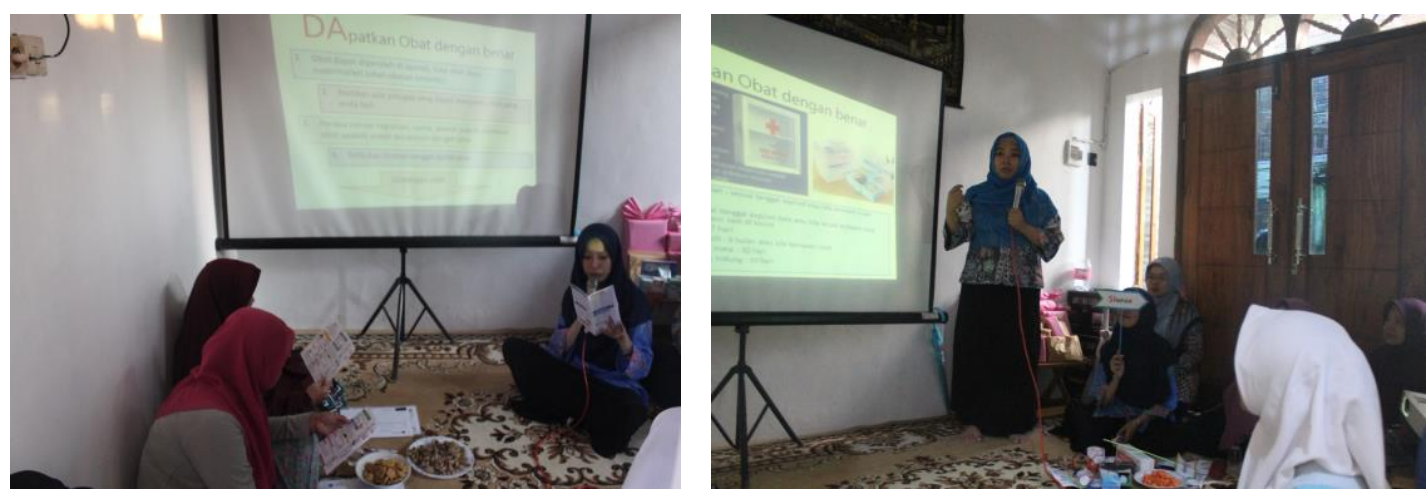

Gambar 1.

Penyuluhan dan Pelatihan Dagusibu 
Tahap 2: Kegiatan Monitoring

Gambar 2 menunjukkan kegiatan monitoring yang dilakukan. Tabel 1 menunjukkan bahwa 97\% responden masih mengingat dan memahami materi yang disampaikan saat penyuluhan satu bulan sebelumnya. Hasil tersebut sesuai dengan harapan yang tercantum dalam Kepmenkes RI Tahun 2015 bahwa penggunaan obat yang rasional dapat tercapai dengan salah satu langkah yaitu meningkatkan pemahaman dan kesadaran masyarakat akan pentingnya penggunaan obat secara benar (Kementerian Kesehatan RI, 2015). Selain itu, sebanyak $15 \%$ responden menjawab salah pada pertanyaan No. 8 yaitu "Apoteker adalah kasir di apotek", hal tersebut menunjukkan bahwa apoteker masih kurang dikenal masyarakat.
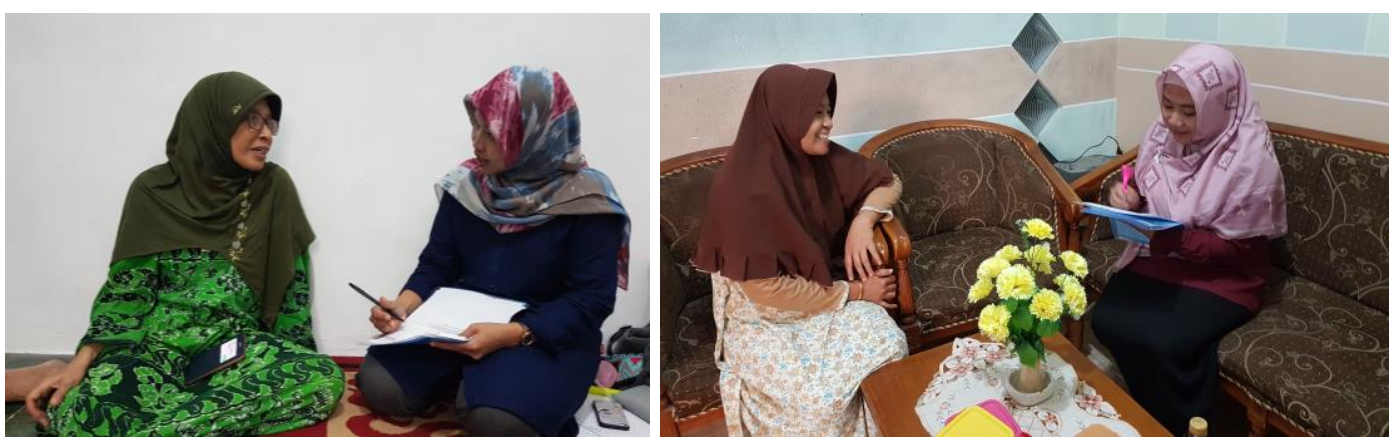

Gambar 2

Monitoring Hasil Pengabdian Masyarakat

Tabel 1.

Hasil Pengetahuan Tentang "Tanya 5 O"

\begin{tabular}{|c|c|c|c|c|c|c|c|c|c|c|}
\hline Pertanyaan No. & 1 & 2 & 3 & 4 & 5 & 6 & 7 & 8 & 9 & 10 \\
\hline $\begin{array}{c}\text { Jumlah Jawaban } \\
\text { Benar }\end{array}$ & 20 & 20 & 20 & 20 & 20 & 20 & 20 & 17 & 18 & 19 \\
\hline $\begin{array}{c}\text { Jumlah Jawaban } \\
\text { Salah }\end{array}$ & 0 & 0 & 0 & 0 & 0 & 0 & 0 & 3 & 2 & 1 \\
\hline
\end{tabular}

Oleh karena itu, kehadiran apoteker yang rutin di apotek dalam menjalankan profesi secara professional dan berinteraksi langsung dengan pasien, termasuk untuk pemberian informasi obat dan konseling kepada pasien yang membutuhkan menjadi sangat penting untuk mengurangi mispersepsi masyarakat terhadap profesi apoteker (Dominica, Putra \& Yulihasri, 2016).

Tabel 2.

Hasil Variabel Dapatkan-Gunakan

\begin{tabular}{|c|c|c|c|c|c|c|c|c|c|c|c|c|c|c|c|}
\hline $\begin{array}{c}\text { Pertanyaan } \\
\text { No }\end{array}$ & \multicolumn{10}{|c|}{ Dapatkan } & \multicolumn{1}{|c|}{ Gunakan } \\
\cline { 2 - 17 } & 1 & 2 & 3 & 4 & 5 & 6 & 7 & 8 & 1 & 2 & 3 & 4 & 5 & 6 & 7 \\
\hline $\begin{array}{c}\text { Jumlah } \\
\text { Jawaban }\end{array}$ & 14 & 17 & 18 & 14 & 14 & 20 & 19 & 19 & 15 & 16 & 19 & 20 & 15 & 17 & 20 \\
\hline
\end{tabular}




\begin{tabular}{|c|l|l|l|l|l|l|l|l|l|l|l|l|l|l|l|}
\hline Benar & & & & & & & & & & & & & & & \\
\hline $\begin{array}{c}\text { Jumlah } \\
\text { Jawaban } \\
\text { Salah }\end{array}$ & 6 & 3 & 2 & 6 & 6 & 0 & 1 & 1 & 5 & 4 & 1 & 0 & 5 & 3 & 0 \\
\hline
\end{tabular}

Menurut Tabel 2, hasil monitoring materi DApatkan obat dengan benar sebanyak $84,38 \%$ responden menjawab benar, sedangkan $15,63 \%$ menjawab salah. Diantara jawaban salah tersebut, terdapat tiga poin pertanyaan dengan jumlah jawaban salah terbanyak yakni sebanyak 6 responden, poin tersebut adalah obat-obatan sebaiknya dibeli di warung, toko kelontong, dan supermarket terdekat. Obat yang dikemas ulang dan tidak ada informasi nomor registrasi dan waktu kadaluarsa, aman di konsumsi, logo hijau dengan bundaran hitam termasuk obat keras.

Hasil monitoring variabel GUnakan, sebanyak 87,14\% peserta penyuluhan masih mengingat cara penggunaan obat yang benar hasil penyuluhan sebelumnya. Sejumah $12,86 \%$ diantaranya menjawab salah terbanyak pada poin 1 dan 5 yaitu "Obat dapat diminum menggunakan the dan susu" dan "Cara penggunaan tetes mata sama dengan salep mata".

Berdasarkan Tabel 3, hasil monitoring variabel SImpan yaitu 76\% menjawab benar keseluruhan pertanyaan dan $24 \%$ sisanya menjawab salah. Diantara $24 \%$ yang menjawab salah, poin 1 dengan pertanyaan "Penyimpanan semua obat berada dilemari" memiliki tingkat kesalahan 40\% terbanyak dibandingkan yang lain. Pada variabel BUang memiliki presentase menjawab benar sebanyak $93 \%$, sedangkan $7 \%$ lainnya menjawab salah. Poin pertanyaan yang memiliki jumlah salah terbesar pada variabel buang adalah 1 dan 3 yaitu "Obat bila berubah warnanya akan bekerja semakin baik" dan "Cara membuang tablet adalah dengan membuang kemasan beserta isinya"

Tabel 3.

Hasil Variabel Simpan - Buang

\begin{tabular}{|c|c|c|c|c|c|c|c|c|c|c|}
\hline \multirow{2}{*}{ Pertanyaan No } & \multicolumn{9}{|c|}{ Simpan } & \multicolumn{7}{c|}{ Buang } \\
\cline { 2 - 12 } & 1 & 2 & 3 & 4 & 5 & 1 & 2 & 3 & 4 & 5 \\
\hline $\begin{array}{c}\text { Jumlah } \\
\text { Jawaban Benar }\end{array}$ & 13 & 18 & 15 & 17 & 14 & 17 & 20 & 17 & 19 & 20 \\
\hline $\begin{array}{c}\text { Jumlah } \\
\text { Jawaban Salah }\end{array}$ & 8 & 2 & 5 & 3 & 6 & 3 & 0 & 3 & 1 & 0 \\
\hline
\end{tabular}

Secara keseluruhan, hasil monitoring peserta penyuluhan Dagusibu satu bulan sebelumnya yang diadakan di RT003/RW003 Desa Kedanyang memperoleh jawaban benar lebih dari $75 \%$, sebagaimana ditunjukkan pada Gambar 3. Hal tersebut membuktikan bahwa metode yang dipilih dalam penyuluhan sudah tepat, dimana masyarakat masih mengingat dan memahami materi yang disampaikan berdasarkan hasil kuisioner. Namun, 
perolehan variabel SImpan yang masih kurang menunjukkan perlunya modifikasi metode sebelumnya yang lebih aplikatif sehingga masing-masing individu dapat memahami lebih baik cara penyimpanan obat yang benar. Tahapan individu untuk memahami dengan baik dengan mempraktekkan langsung materi yang disampaikan seperti dalam konsep Student Centre Learning (Silberman, 2016)

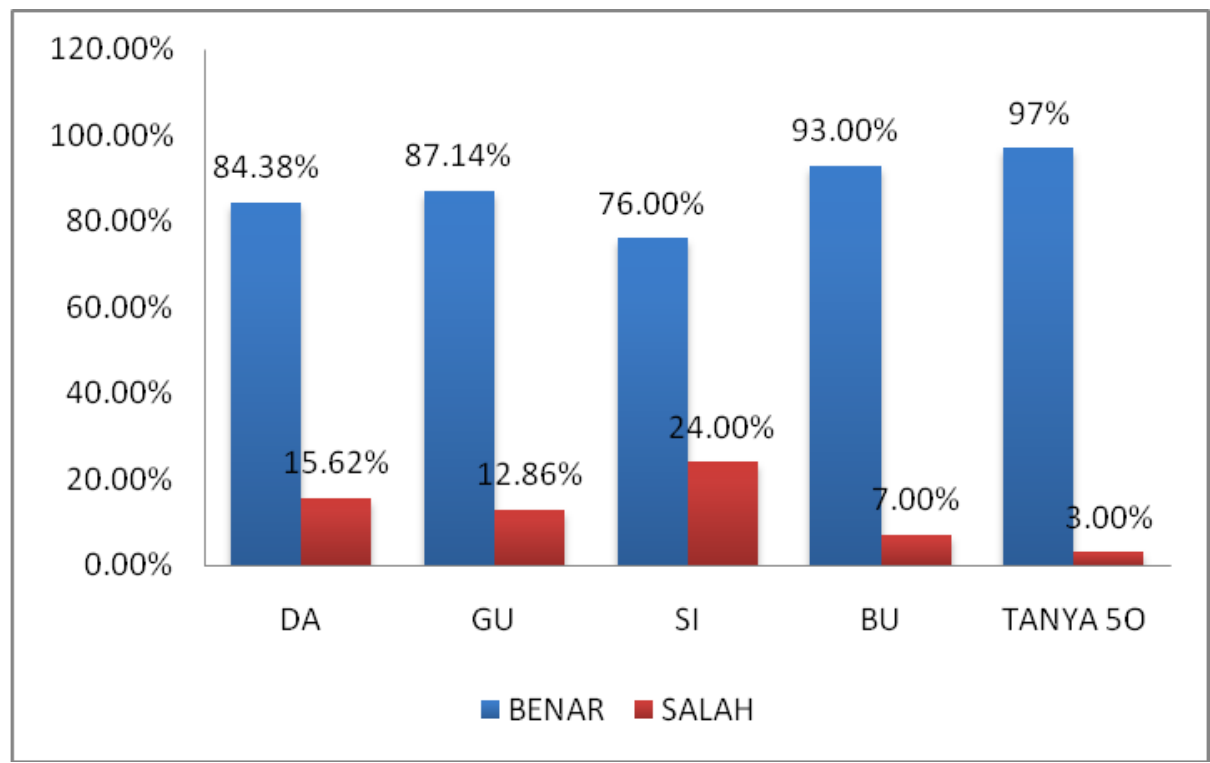

Gambar 3.

Hasil Monitoring Variabel Dagusibu dan Tanya 50 di RT 03/RW003, Desa Kedanyang

\subsection{Kendala yang Dihadapi}

Pelaksanaan kegiatan ini menghadapi berbagai kendala, diantaranya adalah sebagai berikut:

1. Kurangnya kesadaran masyarakat dalam partisipasi kegiatan pengabdian masyarakat

2. Adanya kebiasaan masyarakat terdahulu tentang cara mendapatkan dan penggunaan obat

3. Kurangnya pengetahuan masyarakat tentang bahaya menggunakan dan menyimpan obat yang salah, oleh karena dampak yang tidak terlihat langsung.

\subsection{Dampak}

Peningkatan pengetahuan mengenai Dagusibu obat dengan benar pada ibu-ibu PKK yang merupakan dokter pertama di rumah. 


\subsection{Upaya Keberlanjutan Kegiatan}

Kegiatan pengabdian masyarakat di Desa Kedanyang Gresik merupakan kegiatan yang berkelanjutan. Terdapat 2 tahap dalam kegiatan pengabdian masyarakat di Desa Kedanyang Kecamatan Kebomas, yakni :

\section{Tahap 1: Penyuluhan tentang Dagusibu}

Materi yang disampaikan kepada ibu-ibu PKK RT03/RW03 Desa Kedanyang Gresik meliputi cara mendapatkan obat yang benar, memperoleh informasi petunjuk penggunaan obat tersebut, proses penyimpanan obat yang tepat dan benar supaya mutu obat tetap terjaga. Selain penyimpanan, disampaikan juga materi tentang cara pembuangan obat yang baik dan benar. Obat memiliki berbagai macam bentuk dan kemasannya juga beragam sehingga proses pembuangannya juga tidak boleh sembarangan. Penjelasan lebih lanjut dari materi Dagusibu tersebut adalah sebagai berikut (Budiarti, 2017):

\section{Mendapatkan Obat (Da)}

Berdasarkan Peraturan Pemerintah No. 51/2009, masyarakat seharusnya mendapatkan obat di fasilitas kefarmasian yaitu:

a) Apotek

Apotek merupakan salah satu sarana kefarmasian bagi masyarakat untuk mendapatkan obat dan dibantu oleh tenaga teknis kefarmasian serta apoteker.

b) Instalasi farmasi rumah sakit

Selain apotek, masyarakat dapat menggunakan fasilitas kefarmasian di rumah sakit yaitu Instalasi farmasi rumah sakit

c) Klinik

Definisi klinik merupakan fasilitas pelayanan kesehatan masyarakat yang diselenggarakan perorangan namun pada umumnya hanya menyediakan pelayanan medis dasar yang dipimpin oleh seorang tenaga medis.

d) Toko obat

Toko yang dimaksud dalam kategori ini adalah toko yang telah mempunyai ijin resmi untuk mengedarkan secara eceran obat bebas dan obat bebas terbatas.

Setelah masyarakat memahami tempat yang tepat untuk mendapatkan obat, maka setelah obat tersebut sampai kepada yang bersangkutan maka tindakan berikutnya adalah pemeriksaan fisik dan mutu obat meliputi:

a) Jumlah dan jenis obat

Masyarakat sebaiknya memahami bahwa obat memiliki beberapa jenis yaitu obat bebas dengan logo lingkaran hijau, obat bebas terbatas dengan logo biru, obat narkotika, obat psikotropika serta obat keras dengan logo huruf $\mathrm{K}$ merah. 
b) Kemasan obat

Pada umumnya kemasan obat bertuliskan nama obat, komposisi obat (kandungan zat aktif di dalamnya), indikasi (informasi khasiat obat), aturan pakai (cara penggunaan), perimgatan perhatian (berisi peringatan obat dalam bentuk persegi panjang hitam), tanggal kedaluarsa, nama produsen, nomor batch, harga dan nomor registrasi.

c) Tanggal kedaluarsa

Setelah mendapatkan obat, masyarakat harus teliti dalam melihat tanggal kedaluarsa yang tertera pada kemasan obat. Masih banyak masyarakat yang belum dapat membedakan expired date dengan Manufacturing Date (MFD). MFD adalah tanggal obat diproduksi sedangkan expired date merupakan tanggal kedalursa atau batas akhir obat tersebut dapat dikonsumsi.

\section{Menggunakan Obat (Gu)}

Pada tahap ini, masyarakat diharapkan cerdas dalam menggunakan obat. Pada dasarnya, obat berisi bahan dengan dosis tertentu dan melalui penggunaan yang tepat maka obat tersebut dapat bekerja secara efektif (Depkes RI, 2008). Informasi tentang tata cara penggunaan obat dapat dikelompokkan menjadi:

a) Informasi umum atau garis besar

Masyarakat seharusnya sudah mulai menyadari untuk pandai membaca informasi yang tertera pada etiket atau brosur obat demi ketepatan penggunannya. Penggunaan obat tanpa petunjuk dokter hanya boleh diterapkan pada obat bebas dan obat bebas terbatas pada kondisi masalah kesehatan ringan.

Informasi tentang waktu dan aturan penggunaan obat juga harus dipatuhi oleh masyarakat. Beberapa obat memiliki aturan penggunaan yang harus dihabiskan biasnya berupa antibiotik. Selanjutnya, obat bebas atau obat bebas terbatas tidak dimaksudkan untuk digunakan terus menerus. Ketika mendapatkan obat sebaiknya tidak melepas etiket nya untuk menjaga agar penggunaanya tetap berlangsung dengan baik dan benar.

b) Informasi khusus

Untuk obat oral, maka penggunannya dilakukan secara oral (lewat mulut). Pemberian obat tersebut paling mudah dan praktis. Sediaan obat oral yaitu tablet, kapsul, puyer dan cairan. Petunjuk penggunaan obat padat yaitu sebaiknya diminum dengan air matang dengan memperhatikan waktu dan dosis minumnya. Sedangkan pada kasus cara penggunaan obat dalam sediaan cairan yaitu memakai sendok takar atau alat lain (pipet, gelas takar obat). Salah satu hal yang diperhatikan yaitu tidak menggunakan sendok rumah tangga karena takarannya berbeda dari seharusnya. Selanjutnya, obat 
kumur merupakan obat yang tidak untuk diminum. Kesimpulannya adalah ketika menggunakan suatu obat maka diperhatikan aturan dosisnya serta aturan pakainya.

Obat luar berbeda dengan obat oral. Obat tersebut dibuat untuk tidak dilewatkan saluran pencernaan. Contohnya adalah sediaan kulit, sediaan mata, sediaan obat telinga, sediaan supositoria, sediaan krim/salep, sediaan ovula. Setiap obat tersbut memiliki tata cara penggunaan yang berbeda-beda.

i. Sediaan kulit

Contoh dari obat jenis ini adalah bedak, lotion, krim. Sebelum dan sesudah menggunakan obat tersebut sebaiknya masyarakat mencuci tangan sampai bersih.

ii. Sediaan mata

Obat jenis ini didesain secara steril sehingga komponen didalamnya harus dijaga dengan baik. Penggunaanya dilakukan dengan menengadahkan pasien kemudian diteteskan secara perlahan sesuai petunjuk serta tidak disarankan membasuh menggunakan air hangat.

iii. Sediaan tetes telinga

Tata cara penggunaan obat ini adalah dengan menjauhkan ujung kemasan obat dengan alat penetes telinga atau pipet untuk mencegah kontaminasi. Obat ini diteteskan perlahan sesuai petunjuk setelah telinga dibersihkan.

iv. Sediaan supositoria

Sebelum digunakan, obat jenis ini dibasuh dahulu dengan sedikit air, kemudian pasien berbaring dengan posisi miring kemudian bagian ujung obat tersebut didorong ke dalam anus dengan ujung jari. Selanjutnya sangat dianjurkan untuk mencuci tangan sampai bersih. Apabila obat tersebut lembek dan sulit dimasukkan ke anus maka dapat didingnkan dahulu di lemari pendingin kemudian dialiri air dan dibuka kemasannya.

v. Sediaan krim/salep

Tata cara penggunaan obat jenis ini hampir sama dengan obat sediaan padat.

vi. Sediaan ovula

Sebelum menggunakan obat ini, tangan dan aplikator dipastikan bersih dahulu dari kuman. Pasien berbaring dengan posisi miring kemudian obat dimasukkan melalui vagina menggunakan aplikator.

\section{Menyimpan Obat (Si)}

Beberapa hal yang harus diperhatikan dalam penyimpanan obat sesuai dengan aturan Depkes RI (2008) adalah menjauhkan obat dari jangkauan anak-anak, menyimpan obat dalam kemasan asli dengan wadah tertutup rapat, kondisi penyimpanan di tempat yang sejuk serta obat tidak ditinggalkan di kendaraan dalam waktu yang lama. Sediaan obat 
padat disimpan dengan kondisi sejuk dan terlindung dari cahaya. Sediaan obat cair ditempatkan di lemari pendingin agar tidak beku kecuali pada beberapa obat sesuai etiketnya. Untuk sediaan krim disimpan dalam wadah tertutup rapat dna kondisi sejuk. Obat sediaan ovula harus disimpan dalam lemari pendingin karena akan mencair pada suhu ruangan sedangkan sediaan obat aerosol tidak disimpan dalam tempat dengan suhu tinggi karena dapat menimbulkan ledakan.

\section{Membuang Obat (Bu)}

Masyarakat perlu memahami secara umum tentang pembuangan obat yang telah dikonsumsinya supaya mencegah penyalahgunaan obat serta membantu proses pengolahan limbah dari obat tersebut. Tata cara pembuangan obat yang tepat dan benar adalah penghancuran obat kemudian ditimbun dalam tanah untuk obat padat sedangkan obat cair dibuang dengan cara mengencerkan obat tersebut dan dicampurkan dengan bahan lainnya dengan tanah atau pasir. Selanjutnya, untuk menghindari penyalahgunaan obat maka etiket harus dilepas sebelum membuang obat tersebut. Kemasan box atau dus dan tube sebaiknya digunting atau dipotong dahulu sebelum dimusnahkan.

Di sisi lain, Metode Dagusibu ini dapat diterapkan secara menyeluruh pada lapisan masyarakat khususnya orang dewasa karena informasi proses mendapatkan, menggunakan, menyimpan hingga membuang obat yang telah diperolehnya menjadi sangat penting untuk membentuk masyarakat yang lebih sehat. Metode sosialisasi Dagusibu dapat disebarkan melalui media sosial, metode edukasi, metode ceramah maupun aplikasi melalui demontrasi kecil kepada kalangan masyarakat (Pernatasari, 2017).

\section{Tahap 2: Monitoring}

Monitoring dilakukan satu bulan setelah penyuluhan guna mengetahui keberlanjutan pemahaman peserta penyuluhan sebelumnya dengan metode kuisioner. Terdapat 5 variabel yang diukur dalam monitoring yakni materi "Tanya 50", DApatkan, GUnakan, SImpan, dan BUang. Pada pelaksanaan monitoring, dilakukan juga penyuluhan individual terhadap poinpoin yang salah pada masing-masing individu dengan diskusi maupun praktek langsung dengan obat-obat yang ada di rumah masing-masing.

Tahapan monitoring ini dilakukan untuk memastikan kembali pemahaman setiap individu terkait penyuluhan dan pelatihan yang telah diberikan sebelumnya, sehingga masyarakat dapat mengaplikasikan penggunaan obat yang benar melalui Dagusibu. Keberlanjutan hasil pengabdian masyarakat ini dapat dillakukan secara mandiri oleh Ibu-lbu PKK Desa Kedanyang RT/RW/ 003/003 dan memberikan kesempatan peserta untuk menyebarkan informasi tersebut kepada keluarganya dan masyarakat di Desa Kedanyang. 


\section{KESIMPULAN}

Kegiatan pengabdian masyarakat dengan cara penyuluhan dan pelatihan telah terlaksana dengan baik dan mendapatkan respon yang sangat baik dari peserta, yaitu ibuibu PKK setempat. Pelaksanaan penyuluhan dan pelatihan mengenai obat terutama Dagusibu dapat dikatakan efektif dengan persentase menjawab benar masing-masing variabel diatas $75 \%$, antara lain "Tanya 50" sebanyak 97\%, DApatkan $84,38 \%$, GUnakan $87,14 \%$, SImpan $76 \%$, dan BUang 93\%.

\section{REFERENSI}

Budiarti, I. (2017). Perbandingan Efektivitas Metode Edukasi dalam Upaya Meningkatkan Pengetahuan Ibu tentang Dagusibu. Thesis. Fakultas Farmasi, Universitas Muhammadiyah Purwokerto.

Depkes RI, 2008, Informatorium Obat Nasional Indonesia. Jakarta: Badan Pengawas Obat dan Makanan, Jakarta.

Dominica, D., Putra, D.P., \& Yulihasri. (2016). Pengaruh Kehadiran Apoteker Terhadap Pelayanan Kefarmasian di Apotek di Kota Padang. Jurnal Sains Farmasi \& Klinis, 3(1), 99-107.

Kementerian Kesehatan RI. (2014). Riset Kesehatan Dasar 2013. Diunduh dari http://depkes.go.id/downloads/riskesdas2013/Hasil\%20Riskesdas\%202013.pdf.

Kementerian Kesehatan RI. (2015). Keputusan Menteri Kesehatan RI Nomor HK. 02.02/ MenKes/427/2015 tentang Gerakan Cerdas Masyarakat Menggunakan Obat (GeMa CerMaT). Jakarta.

Permatasari, R, (2017), Efektivitas Penggunaan Media Sosial Berupa Facebook dan Instagram untuk Meningkatkan Pengetahuan Mahasiswa Non Kesehatan tentang Dagusibu di Universitas Muhammadiyah Purwokerto. Thesis. Fakultas Farmasi, Universitas Muhammadiyah Purwokerto.

Republik Indonesia. 2009. Peraturan Pemerintah No. 51 Tahun 2009 tentang Pekerjaan Kefarmasian. Jakarta: Sektretariat Negara RI.

Silberman, M.L. (2016). Active Learning: 101 Cara Belajar Siswa Aktif. Bandung: Nuansa Cendekia. 